\title{
Renata Wiaderna-Kuśnierz
}

Pomeranian University in Słupsk, Poland

ORCID: 0000-0001-7427-2701

renata.wiaderna-kusnierz@apsl.edu.pl

\section{An Unknown Episode from the Life of Marceli Chlamtacz, a Lwów-based Professor of Roman Law: A Few Words on the Election and Candidates for the Post of Secretary at the University of Lwów in the Academic Year 1894/95}

\author{
Nieznany epizod z życia Iwowskiego profesora prawa rzymskiego \\ Marcelego Chlamtacza, czyli słów kilka o wyborach i kandydatach \\ na stanowisko sekretarza Uniwersytetu Lwowskiego w roku \\ akademickim 1894/95
}

\section{SUMMARY}

At the end of 1894, the University of Lwów announced a public competition for the position of the secretary of the university. A few months later the university received seven applications from young lawyers. As it turned out later the winner was Marceli Chlamtacz - a Roman law scholar, for whom it was one of the steps of his academic career. In the first part of the paper, I discussed, among others, circumstances of the elections and professional achievements of candidates until the time of elections. In the second one, were presented results of the elections and illustrated careers of competing lawyers that they had after 1895. Apart from M. Chlamtacz other persons famous in the later years applied for the position: Aleksander Doliński - professor of commercial law at Lwów's Jan Kazimierz University, co-author of the Polish Commercial Code; Tadeusz Bujak - judge of courts in Kraków, Vienna and Warsaw; Jan Wierzbowski - attorney and judge in Stanisławów, philanthropist and donor of the Lwów's Scientific Society; Jan Waygart - held a degree of doctor of law, specialist in military justice, Under-Secretary of State in the Ministry of Military Affairs; Jan Błeszyński doctor of law at the Jagiellonian University in Kraków, expert in the field of theater, literature and translations. The last one who applied for the above-mentioned position was widely unknown alumni of law Kazimierz Tychowski, a Ukrainian.

Keywords: University of Lwów; Jan Kazimierz University; Roman law; civil law; commercial law; Lwów; Kresy; Marceli Chlamtacz; Aleksander Doliński; Tadeusz Bujak; Jan Józef Wierzbowski; Jan Waygart; Kazimierz Tychowski; Jan Błeszyński; judge; lawyer 


\section{INTRODUCTION}

As the $155^{\text {th }}$ anniversary of the birth of Marceli Stanisław Chlamtacz ${ }^{1}$ has just passed this year, the article aims to recall one of the unknown episodes from the life of this increasingly rediscovered professor of the Francis I University of Lwów, operating as Jan Kazimierz University after World War I, who specialized in Roman and civil law. His life and activity are drawing more and more attention from subsequent researchers. After his death in 1947, only a few short articles or biographical entries concerning him came out ${ }^{2}$, however, in the last several years he has been mentioned by, i.a., Adam Redzik ${ }^{3}$, Bożena Czech-Jezierska ${ }^{4}$ and Renata Kamińska ${ }^{5}$. The author of these words also has published several publications about the life and work of M. Chlamtacz, including the monograph Roman Law at the Jan Kazimierz University in Lwów in the Interwar Period 1918-1939 (Prawo rzymskie na Uniwersytecie Jana Kazimierza we Lwowie w okresie międzywojennym 1918-1939, Toruń 2015, 20176). Grzegorz Nancka has also recently published

1 Marceli Chlamtacz was born on 26 April 1865 in Szarpańce, Podole.

2 For example, see W. Osuchowski, Marcel Chlamtacz (1865-1947) [nekrolog], „Czasopismo Prawno-Historyczne” 1949, vol. 2, pp. 503-507; idem, Chlamtacz Marceli, [in:] Biogramy uczonych polskich: materiały o życiu i działalności członków AU w Krakowie, TNW, PAU, PAN, part 1: Nauki społeczne, issue 1: A-J, Wrocław 1983, p. 189; A. Śródka, Uczeni polscy XIX-XX stulecia, vol. 1: $A-G$, Warszawa 1994, p. 245.

3 A. Redzik, Wydziat Prawa Uniwersytetu Lwowskiego w latach 1939-1946, Lublin 2006, passim; idem, Prawo prywatne na Uniwersytecie Jana Kazimierza we Lwowie, Warszawa 2009, passim; idem, Nauki prawne na Uniwersytecie Lwowskim, [in:] Universitati Leopoliensi trecentessimum quinquagesimum anniversarium suae fundationis celebranti In memoriam, Kraków 2011, pp. 145-183; idem, O naukach historyczno-prawnych w Uniwersytecie Jana Kazimierza we Lwowie, [in:] Nauki historycznoprawne w polskich uniwersytetach w II Rzeczypospolitej, ed. M. Pyter, Lublin 2008, pp. 131-185.

4 B. Czech-Jezierska, Nauczanie prawa rzymskiego w Polsce w okresie międzywojennym, Lublin 2011, passim; eadem, Okres dwudziestolecia międzywojennego a rozwój nauki prawa rzymskiego, „Zeszyty Prawnicze” 2011, no. 11.4, DOI: https://doi.org/10.21697/zp.2011.11.4.07, pp. 161-188; eadem, Prawo rzymskie i jego nauczanie w Polsce, [in:] Synteza prawa polskiego 1918-1939, eds. T. Guz, J. Głuchowski, M.R. Pałubska, Warszawa 2013, pp. 946-981.

5 R. Kamińska, Marcelego Chlamtacza walka o realny charakter umowy, [in:] Ad laudem magistri nostri. Mistrzowie. Dzieła polskiej romanistyki, Toruń 2018, pp. 81-95.

6 See also R. Wiaderna-Kuśnierz, Nauka i nauczanie prawa rzymskiego na Uniwersytecie Lwowskim w pierwszej polowie XX wieku, „Studia Prawnoustrojowe” 2007, vol. 7, pp. 307-317; eadem, Prawo rzymskie i romaniści na łamach lwowskiego „Przegladu Prawa i Administracji” (1876-1939), [in:] Quid leges sine moribus? Studia nad prawem rzymskim dedykowane Profesorowi Markowi Kuryłowiczowi w 65. rocznice urodzin i 40-lecie pracy naukowej, ed. K. Amielańczyk, Lublin 2009, pp. 221-239; eadem, Wybory rektora na Uniwersytecie Jana Kazimierza we Lwowie w 1933 roku w świetle nowej ustawy o szkołach akademickich, [in:] Społeczeństwo a władza. Ustrój, prawo, idee, eds. J. Przygocki, M. Ptak, Wrocław 2010, pp. 727-773; eadem, Zagraniczne studia i stypendia naukowe romanistów Uniwersytetu Jana Kazimierza we Lwowie, „Zeszyty Prawnicze” 2015, no. 4, DOI: https://doi.org/10.21697/zp.2015.15.4.10, pp. 189-213. 
the monograph entitled Roman Law in the Works of Marceli Chlamtacz (Prawo rzymskie w pracach Marcelego Chlamtacza, Katowice 2019) ${ }^{7}$.

Despite publications by the above authors, many details of the life and activity of M. Chlamtacz have never been made public. The same applies to the circumstances of his election as secretary and notary of the University of Lwów in the 1894/95 academic year. Therefore, this article aims to shed light on this matter with the application of the historical research method. Also, the article reveals some unknown facts from the lives of famous Polish barristers such as Aleksander Doliński, Tadeusz Bujak, Jan Waygart and Józef Wierzbowski who had also applied for this post. Another aim of the article is to depict how they pursued their careers after their candidacies had been rejected. The essay also describes unknown facts from the Lwów archives which are made public for the first time.

\section{THE ANNOUNCEMENT OF A VACANCY FOR THE POST OF SECRETARY AT THE UNIVERSITY OF LWÓW}

A secretary, who was also a notary of the University of Lwów, was part of the so-called University Chancellery. The university Rector was the head of the Chancellery. Apart from the secretary, the Chancellery also employed a questor and kancelista $^{8}$ (archaic Polish: clerks) and dietariusz ${ }^{9}$ (archaic Polish: junior clerks). The Chancellery included the Service of documents and sending university acts (in Polish: Biuro doręczeń i ekspedycja aktów uniwersyteckich) as well as university building management (in Polish: Zawiadowstwo gmachu uniwersyteckiego) that was the responsibility of the pede $1^{10}$ at the university ${ }^{11}$.

Because Stanisław Szachowski ${ }^{12}$, the secretary of the University at the time, was appointed professor extraordinarius of Roman law on 25 October $1894^{13}$, the Senate of the Francis I University of Lwów announced a vacancy to fill his post. The announcement of the vacancy dated 7 December 1894 appeared in "Gazeta

7 Grzegorz Nancka is also the author of two articles concerning the topic: Trzej romaniści w pogladach Marcelego Chlamtacza, „Studia Prawno-Ekonomiczne” 2017, vol. 105, pp. 45-66; Kilka uwag o pogladach Marcelego Chlamtacza na regułę bonae fidei possessor fructus/ consumptos/ suos facit, „Z Dziejów Prawa” 2018, vol. 11(19), part 2, pp. 29-46.

8 Chancellery writers signing documents with their names. Junior clerks.

9 Junior clerks not employed full-time but receiving remuneration.

${ }^{10}$ Outdated: janitor.

${ }^{11}$ Kronika Uniwersytetu Lwowskiego 1894/95-1897/98, eds. L. Finkel, M. Chlamtacz, vol. 1, Lwów 1899, pp. 254-255.

12 See A. Redzik, R. Wiaderna-Kuśnierz, Szachowski Stanisław Krzysztof (1838-1906), [in:] Polski Stownik Biograficzny, Warszawa 2010, pp. 360-363.

13 After 15 years as secretary Szachowski resigned from the post. See Kronika Uniwersytetu Lwowskiego 1894/95-1897/9, p. 30, 123. 
Lwowska" on 13 and 15 December (no. 284, p. 7 and no. 286, p. 8) in the column called "Konkursa". The announcement said:

In order to fill the post of University secretary at the local Imperial-Royal (I-R) University that carries salary of class IX clerks, we hereby announce a vacancy to be filled by 31 January 1895 . Applicants should hold certificates of law studies with good grades in theoretical state examinations and submit evidence of their age, status, abilities, work experience or other performed jobs, and finally certificates confirming their knowledge of the official languages and German. Applicants who are already civil servants should submit their applications through their superiors while all other applications should be submitted directly to the Senate of I-R University in Lwów. University Senate of I-R University. Lwów, 7 December, 1894.

\section{MARCELI CHLAMTACZ'S APPLICATION}

Seven candidates submitted their applications for the vacancy including five doctors of law among them Marceli Chlamtacz, doctor of law at the University of Lwów (since 1891). In 1894, Chlamtacz returned from Germany where he had continued his studies of Roman and civil law for three years ${ }^{14}$. Soon after his return from Berlin to Lwów, he resumed his law practice, and on 29 January 1895, he applied for the above-mentioned post of the University secretary ${ }^{15}$. In his application, the longest of all the submitted ones ${ }^{16}$, he presented his career and professional path as follows:

Having graduated from gymnasium and passing the final matriculation exam in 1885 , I continued my education at the University of Lwów where I studied law and passed three state examinations within the prescribed time period. As I was planning to become a barrister, I completed an obligatory criminal court placement at the Imperial-Royal National Court at the $1^{\text {st }}$ Instance Tribunal in Lwów in 1890 and 1891. During the same period of time, I successfully passed the qualifying examinations and was awarded the degree of doctor of laws at the University of Lwów. Afterward, I embarked on my barrister training at barrister dr Paweł Dąbrowski’s law firm in Lwów. Feeling enslaved, I decided to terminate it less than one year into the training, and head for Vienna. In the academic year 1891/92, I attended the University of Vienna where I studied private law, common law and Austrian law for two semesters. As I had been supported by the esteemed Professors of the Faculty of Law

14 After his return, he lived at Jagiellońska 24, Lwów. See Державний архів львівської області (hereinafter: ДАЛО), ф. 26, оп. 5, спр. 1989, арк. 5v. About Marceli Chlamtacz's foreign studies, see R. Wiaderna-Kuśnierz, Zagraniczne studia i stypendia naukowe...; eadem, Prawo rzymskie na Uniwersytecie Jana Kazimierza we Lwowie w okresie międzywojennym (1918-1939), Toruń 2015, pp. 183-186, 282-289.

15 ДАЛО, ф. 26, оп. 5, спр. 1989, арк. 5.

16 It was possible to establish most of the facts concerning the candidates on the basis of their comprehensive applications and attachments where they described their professional and scholarly careers. Unfortunately there are only few attachments that they had included with their applications as they were later returned to the candidates. Marceli Chlamtacz and Tadeusz Bujak submitted comprehensive applications. 
and Administration in Lwów, I was awarded a two-year imperial scholarship thanks to which I could go to Berlin where I dedicated myself almost entirely to the study of Roman law with a special focus on its historical development. The certificates written by the professors of Berlin University which I enclose define the content and direction of my studies and confirm my command of spoken and written German language. Having returned from my scholarships abroad towards the end of 1894, I commenced my professional practice as a barrister at dr Tadeusz Skałkowski's law firm where I am still working. In order to receive veniam legendi in Roman law at the University of Lwów, I am working on a dissertation on the conventional character of tradition in classical Roman law which I intend to submit to be published this year. To prove that I also have a good command of spoken and written Ukrainian [archaic Polish: ruski], I submit two certificates to confirm that I also studied Ukrainian at the Lwów-based Franz Josef I Gymnasium ${ }^{17}$.

Finally, he justified his request for the post as follows:

In the end, I dare assure the Esteemed Senate that both my efforts so far and responsibilities involved in the new post, would be fulfilled with my utmost conscientiousness, zeal and loyalty if the Esteemed Senate did me the honor to appoint me for the post ${ }^{18}$.

He had included 20 attachments which were not found in the documentation (the included attachments were returned to the rejected candidates).

\section{MARCELI CHLAMTACZ' COUNTER-CANDIDATES}

Counter-candidates to Marceli Chlamtacz were: Jan Józef Wierzbowski - adjunct of the local court in Mikulińce ${ }^{19}$, dr Jan Błeszyński - doctor of law from Jarosław, dr Aleksander Doliński - the candidate of the bar, Kazimierz Tychowski - Imperial-Royal (I-R) administration clerk (kancelista administracyjny), dr Tadeusz Bujak - adjunct of the Imperial-Royal State Treasury (Prokuratoria Skarbu) and dr Jan Waygart - an office clerk (archaic Polish: koncypient ${ }^{20}$ ) of the Imperial-Royal State Treasury ${ }^{21}$.

The first counter-candidate to Chlamtacz for the post of university secretary was Jan Józef Wierzbowski born in 1861 in Skałat, marital status - single, adjunct at the local court in Mikulińce. In the table concerning "Command of languages and other information and skills" of the questionnaire which he had completed on 20 January 1895, he wrote: Polish, Ukrainian, German, certificates of barrister and judicial examinations. The table concerning "Service up-to-day" says, i.a., that he embarked on his placement at the I-R regional court in Stanisławów on 28 April 1885, then he worked for I-R local courts: in Tyśmienica from 6 August 1888,

\footnotetext{
17 ДАЛО, ф. 26, оп. 5, спр. 1989, арк. 4-5.

18 Ibidem.

19 At present: Mykulyntsi, Sniatyn raion, Ivano-Frankivs'k oblast, Ukraine.

${ }^{20}$ Koncypient, koncepista - archaic Polish: 'junior clerk, office clerk, notary clerk, paralegal'.

${ }^{21}$ R. Wiaderna-Kuśnierz, Prawo rzymskie na Uniwersytecie Jana Kazimierza ..., p. 184.
} 
in Dowaczów from 7 August 1888, and in Husiatyn from 28 September $1888^{22}$. Because Wierzbowski was already a civil servant, he submitted his application on 26 January 1895 (register number 416) according to the announcement in "Gazeta Lwowska" through his superior Teofil Niedźwiński, president of I-R local court in Mikulińce. However, Wierzbowski did not wait for the results to be announced and withdrew his application thus resigning from the procedure on 2 February. The following note on his application says: "I hereby waive my request and confirm receiving all the documents I enclosed, Lwów, 2 February 1895. Jan Józef Wierzbowski"23.

On 29 January 1895, there were three more applications. They were submitted by Jan Błeszyński (register number 419), Aleksander Doliński (register number 420) and Marceli Chlamtacz (register number 424).

Very little is known about Jan Błeszyński. Some archival files show his name as Jan Bleszyński, others as Błeszyński. It was established that his real name was Jan Honoriusz Ignacy Abdon Błeszyński. According to the information included in his application, he was born in Skoraczewo in 1865 in the Posen Region (the Grand Duchy of Posen) and lived in Jarosław. The results of the research confirm that the above information tie in with the data found in Dworzaczek's Files (Teki Dworzaczka) on the Internet website of Kórnik Library which belongs to the Polish Academy of Sciences (PAN) as well as in "Gazeta Warszawska" and in Jan Michalik's The History of the Theater in Kraków in 1865-1893: Theater Companies (Dzieje teatru w Krakowie w latach 1865-1893: przedsiębiorstwa teatralne, part 1). They confirm that he was born on 16 June 1865 and his parents were Bonawentura Błeszyński (Suche Komnaty or Oksza coats of $\operatorname{arms}^{24}$ ) and Elżbieta Szczaniecka (Ossorya coat of arms $)^{25}$. After the January Uprising, Bonawentura - his father - was charged in a great political trial which began on 7 July 1864 at the Tribunal in Berlin for 149 participants of the uprising ${ }^{26}$. Bonawentura was accused of delivering arms and weapons for the insurgents and the public prosecutor sought a 6-year prison sentence for him ${ }^{27}$. Jan lived in his mother's estate in Skoraczewo near Kościan until 1874 when his parents sold it and went to live in Kołdowo, Suliszewice farm. Later he lived in his father's estate in Suliszewice. Jan had four siblings: Bronisła-

${ }^{22}$ ДАЛО, ф. 26, оп. 5, спр. 1989, арк. 7.

${ }^{23}$ Ibidem, арк. 6.

${ }^{24}$ Source: http://teki.bkpan.poznan.pl/search.php?section=3\&single=1\&fileno=4\&page=45 [access: 28.12.2019]. Cf. www.sejm-wielki.pl/b/dw.38418 [access: 28.12.2019].

${ }^{25}$ Source: http://teki.bkpan.poznan.pl/search.php?section=3\&single=1\&fileno=4\&page $=45$ [access: 28.12.2019].

${ }^{26}$ www.genealogia.okiem.pl/powstanies/index.php?nazwisko=B $\% \mathrm{C} 5 \% 82$ eszy $\% \mathrm{C} 5 \% 84$ ski [access: 28.12.2019].

${ }^{27}$ Proces wytyczony Polakom w Berlinie, „Gazeta Warszawska” 1864, no. 285, p. 4. 
wa, Ignacy, Antonina and $\mathrm{Maria}^{28}$. He was awarded his matriculation certificate in St. Anna's Gymnasium in Kraków in 1884. He enrolled in a course at the Faculty of Philosophy at Jagiellonian University for the winter semester of 1884/85. He intended to attend lectures in history, history of literature and participated in classes on philosophical doctrines. However, he was not registered as a student in the summer semester ${ }^{29}$. In 1889, he was an extra and an actor in the Kraków Theatre and he published (in his own scope) a sixty-page-long leaflet titled Mr. Glikson's Reign at the Kraków Theater (Rzady Pana Gliksona w Teatrze Krakowskim) where he gave a very critical picture of the four-year-long management of the theatre by the director. The brochure evoked a wide response in Kraków. A lot was written about it and its author. Some perceived it as libel, others as a display of youthful sense of humour, still others as an attempt by an author unexperienced in the matters of the theatre. Jan Michalik wrote broadly about Błeszyński's leaflet and all the responses concerning the functioning of the theatre in the period in question in his publication: The History of the Theater in Kraków in 1865-1893: Theater Companies (Dzieje teatru $w$ Krakowie w latach 1865-1893. Przedsiębiorstwa teatralne) ${ }^{30}$. Probably his work for the theatre was his additional activity as he was studying law and was awarded the title of doctor of laws at the Jagiellonian University in 1891. It was impossible to find out much about his life from 1891 to 1895 when he applied for the post of secretary apart from the fact that he lived in Jarosław at the time of his application for the post at the University of Lwów.

Another candidate for the post of secretary was Aleksander Doliński born on 18 February 1866 in Laskowce ${ }^{31}$. He graduated from the gymnasium in Buczacz and Tarnopol and then studied at the University of Lwów where he was also awarded the title of doctor (1890). After that, he studied in Germany for two years. In the academic year 1890/91 he studied in Berlin taking part in the seminars taught by Alfred Pernice, Heinrich Dernburg and Ernst Eck, professors of Roman law, and in the seminar taught by Levin Goldschmidt, professor of commercial law. During his stay in Göttingen, he also attended seminars taught by Rudolph von Jhering, professor of Roman law, the precursor of solidarity and the author of the "theory of interest" ("Jurisprudence of interests") in 1891/92. On 21 July 1893, he applied for the veniae legendi in Austrian private law at the Faculty of Law. He presented his work: Haftung des Contrahenten für seine Gehilfen bei der Abschließung von obligatorischen Verträgen which was met with criticism from his reviewers - Ernest

${ }^{28}$ Source: http://teki.bkpan.poznan.pl/search.php?section $=3 \& \operatorname{single}=1 \&$ fileno $=4 \&$ page $=45$ [access: 28.12.2019].

29 J. Michalik, Dzieje teatru w Krakowie w latach 1865-1893. Przedsiębiorstwa teatralne, Kraków 1996, p. 400.

${ }^{30}$ Ibidem, pp. 400-405.

${ }^{31}$ At present: Laskivtsi, Ternopil oblast, Ukraine. 
Till and Leonard Piętak ${ }^{32}$. In his application for the post of secretary, he informed that he had been working as a paralegal at the Bar since 7 October $1893^{33}$.

On 31 January 1895, another application registered as application number 427 was submitted by Kazimierz Tychowski - I-R junior administration clerk (archaic Polish: koncepista administracyjny) who was born in 1862 in Hoszany ${ }^{34}$, Rudki county in Galicia. He was Ukrainian socialist ${ }^{35}$. It is known that he was arrested in 1882 when he was a student at the Faculty of Philosophy, University of Lwów. As "Gazeta Toruńska" informs on 13 May 1883, three days before, the verdict was passed against him and fifty other comrades, i.a. Jan Kozakiewicz and Michał Drabik, for promoting socialist ideas and organizing illegal socialist clubs ${ }^{36}$. In this trial, Tychowski was sentenced to 6 months of maximum security prison ${ }^{37}$.

On 2 February 1895, the University of Lwów received two more applications submitted by Tadeusz Bujak ${ }^{38}$ (L. 431) and Jan Waygart (L. 432) (39 $^{39}$ They were sent through their superior dr Karol Kunz - court advisor and the Attorney of the Treasury (Prokurator Skarbu). Both candidates worked for the Office of the Attorney of the Treasury, the first one as an adjunct, the latter as a junior administration clerk.

Tadeusz Bujak was born on 5 February 1862 in Lwów. He came from a Protestant family who settled down in Śląsk Cieszyński. After he had graduated from the Gymnasium I in Lwów in 1879, he embarked on his studies in Lwów and Vienna. He completed his education in 1887 when he was awarded the title of doctor of laws at the University of Lwów ${ }^{40}$. The Office of the Attorney of the Treasury received Bujak's application together with 16 attachments (i.a. birth certificate, graduation certificate, certificates of state examinations, diploma of doctor of law) on 3 January 1895 (L. 280). The application says that he started his career in the Office of the Attorney of the Treasury on 25 October 1883. At that time, he was referred by the decree of I-R National Directorate of the Office of the Attorney of the Treasury for a placement to work without remuneration as

32 A. Redzik, Aleksander Doliński (1866-1930). Profesor prawa handlowego Uniwersytetu Jana Kazimierza we Lwowie, „Czasopismo Prawno-Historyczne” 2007, vol. 59(2), pp. 291-292; Kronika Uniwersytetu Lwowskiego 1894/95-1897/98, pp. 133-134. See also ДАЛО, ф. 26, оп. 5, спр. 1989, арк. 28.

33 Ibidem.

${ }^{34}$ At present: Hradivka, Rudky raion, Lviv oblast, Ukraine.

35 See L. Beskid, K. Zagórski, Robotnicy na tle przemian struktury społecznej w Polsce, Warszawa 1971, p. 376.

${ }^{36}$ W. Reger, A. Gilewicz, Listy Witolda Regera wysłane w latach 1896-1902 z Przemyśla do Londynu do Związku Socjalistów Polskich, Przemyśl 1961, p. 29; W. Najdus, Polska Partia Socjalno-Demokratyczna Galicji i Ślaska: 1890-1919, Warszawa 1983, p. 71.

37 Przegląd dzienny, „Gazeta Toruńska” 13.05.1893, no. 108, p. 2.

${ }^{38}$ His full name: Tadeusz Adolf Jan Teodor Bujak. See ДАЛО, ф. 26, оп. 5, спр. 1989, арк. 12.

39 Ibidem, арк. 16v, $17 \mathrm{v}$.

${ }^{40}$ Ibidem, арк. 12. 
a junior administration clerk at I-R Lwów Office of the Attorney of the Treasury. He was promoted in the following years and received payment of 500-600 złotys annually. By the Decree of 24 June 1890, he was promoted to junior administration clerk (archaic Polish: koncepista) class X, while on 15 June 1892 he was promoted to an adjunct class IX at the same Office of the Attorney of the Treasury ${ }^{41}$. His superiors thought very highly of him. His application form about his career includes the following comment:

He has excellent skills and broad knowledge of acts and the ability to apply them. He is truly devoted and passionate towards his service, fulfills his duties and tasks with zeal, diligence and great conscientiousness. His behavior is exemplary in any consideration. Lwów, 23 February 1892, Betzikowski m.p. (official stamp). Read by Kunz m.p., Lwów, 2 March 1892.

Submitting the application for the post of notary, dr Fryderyk Ruebenbauer super-adviser at the Office of the Attorney of the Treasury presented the following opinion:

If a candidate devotes himself passionately to theoretical law studies and at the same time acquires skills of the practical application of legal acts also and mainly in terms of research and interpretation of them throughout his service for the I-R Office of the Attorney of the Treasury, I consider him to be especially talented to take up the post of secretary of the I-R Office of the Attorney of the Treasury. Lwów, 26 January 1895. Dr Fryderyk Ruebenbauer m.p, I-R senior adviser at the I-R Office of the Attorney of the Treasury. I read it and I agree. Kunz m.p. The I-R Attorney of the Treasury ${ }^{42}$

At that time, dr Tadeusz Bujak declared to be single and to have a command of "basic French and English"43. Apart from his employment in the I-R Office of the Attorney of the Treasury in the 1890s, he worked for the Department of Law Society in Lwów and, on i.a. 23 and 30 October 1890, he presented his report on conditional sentence according to $\S 25$ of the draft of the criminal law, on 28 January and 4 February 1892 - on bidding terms and conditions for sales of property at property auctions, and on 6 and 13 May the same year he reported on the resolutions of chapter V of a project on "The reasons to exclude, mitigate or annul punishment" ( $§ 55-75)$. Bujak was also good at organizational tasks. In 1889, he started a chess club in the Academic Library. He was considered one of the best chess players in Lwów from mid-1880s. In 1894, he was one of the 45 founders of Lwów Chess Club and he was nominated for the position of librarian at the first board meeting ${ }^{44}$. The

${ }^{41}$ Ibidem, арк. 14, 14v.

${ }^{42}$ Ibidem, арк. 12.

${ }^{43}$ Ibidem, арк. 14v, 28.

${ }^{44}$ T. Wolsza, Tadeusz Bujak (1862-1926), [in:] Arcymistrzowie, mistrzowie, amatorzy... Stownik biograficzny szachistów polskich, vol. 4, Warszawa 2003, pp. 17-18. 
club was established on 25 November at a general meeting of chess players in the Grand Hotel in Lwów ${ }^{45}$.

The other candidate, Jan Eugeniusz Juliusz Waygart - junior administration clerk - was born on 5 May 1870 in Macoszyn (Źółkiew county, Lwów district) in a landlord family. In the second half of the $19^{\text {th }}$ century, the Waygarts were owners of Macoszyn. Jan studied in Lwów and was awarded the title of doctor of law at the Faculty of Law and Political Skills in the 1893/94 academic year ${ }^{46}$. He was one of the founders of the first academic society in Lwów, namely "Fencing Club". He was appointed its first chairman at the first general meeting of the club in $1891^{47}$. He also held the position of chairman in the following year ${ }^{48}$.

\section{FILLING THE VACANCY}

The Academic Senate took only two candidates from the above-mentioned ones into consideration namely, Marceli Chlamtacz and Tadeusz Bujak. At the meeting on 16 February 1895, the decision to present only Marceli Chlamtach for the post of the University secretary to the minister finally passed by a majority of votes ${ }^{49}$. The Minister of Religious Affairs and Education appointed him for the post of secretary at I-R University in Lwów by the rescript of 10 May 1895 (L. 9164) and assigned 110 złotys annual pay. Chlamtacz was also entitled to receive a five-year allowance and an activation allowance of 300 złotys annually. The designation became valid on 1 June 1895 by the Official Letter from the Minister of Religious Affairs and Education of 7 June that year and the Academic Senate was authorized to deliver the designation decree to the newly appointed secretary together with the

45 J. Jaremko, Czy wiele krajów ma tak stawna historię?, www.kuriergalicyjski.com/historia/ 8132-czy-wiele-krajow-ma-tak-slawna-historie [access: 14.01.2020].

${ }^{46}$ Apart from him, in this academic year the title of doctor of laws was also awarded to: Jakób Andermann, Józef Herzig, Samuel Herz Marcussohn, SchlomaWassermann, Jonasz Wiesenberg, Witold Roman Sienkiewicz, Joachim Salomon Krug, Sesigrecte Feliks Goldscheider, Gerschon Zipper, Adam Ludwig Leliwa Pilecki, Michał Władysław Lemiszewski, Mojżesz Leib Pachtmann, Kazimierz Promiński, Izaak Presser, Maksymilian Fried, Franciszek Aleksander Bogorya Podlewski, Nason Fichner, Franciszek Sawa, Arnold Hansel, Mieczysław Karol Podczaszyński, Schloma Salman Oberländer, Izaak Leib Schneidmesser, Abraham Halpern, Bronisław Stanisław Morawski, Ernest KonradAdam, Jakób Vorzimmer, Izrael Rotstein, Maksymilian Liptay, Michał Jonasz Landau, Władysław Gawański, Artur Antoni Stanisławski, Łazasz Zion, at the Faculty of Philosophy: Bronisław Ludwik Gubrynowicz and Eugeniusz Mikołaj Romer. See Promocye doktorskie, „Gazeta Lwowska” 11.08.1894, no. 183, pp. 2-3.

47 S. Zaborniak, Sportowe organizacje studenckie Lwowa i Krakowa działajace przed rejestracją Akademickiego Związu Sportowego w 1909 r., [in:] Akademicka kultura fizyczna na przełomie stuleci, vol. 2: Uwarunkowania historyczno-socjologiczne, Krosno 2009, p. 21.

48 T.Z., Z dziejów rozwoju szermierki w Polsce, „Stadjon” 1927, no. 6, p. 4.

49 R. Wiaderna-Kuśnierz, Prawo rzymskie na Uniwersytecie Jana Kazimierza ..., p. 184. See also ДАЛО, ф. 26, оп. 5, спр. 1989, арк. 27v. 
annexes of competence application and order him to report and take on his official duties immediately. They were also asked to inform I-R Governorship about the designation and assignation of his salary and finally to inform the other candidates applying for the post that it is already filled and return their applications with all enclosed documents. It was also mentioned that the attachments submitted by Tadeusz Bujak had been returned to him on his demand immediately" 50 .

Marceli Chlamtacz took on his duties as University secretary on 1 June 1895 to work at his post for 5 years until he was appointed professor extraordinarius of Roman law at the University on 12 June 1990. His successor to the position was Alojzy Winiarz - private university associate professor (in Polish: docent prywatny uniwersytetu), adjunct of national archive of the town and land files in Lwów ${ }^{51}$.

While fulfilling his secretarial duties as University secretary, Chlamtacz took upon himself the task of editing the first volume of the chronicles of the University of Lwów entitled The Chronicles of the University of Lwów (1894/95-1897/98) (Kroniki Uniwersytetu Lwowskiego [1894/95-1897/98]) in cooperation with Ludwik Finkel. The following people were his co-workers at the University Chancellery: Ananiasz Ardan - questor, Franciszek Owoc and Mieczysław Świątkiewicz - junior administration clerks (kanceliści), Franciszek Krzyżanowski - permanently employed junior clerk (dietariusz), Jan Pniak - janitor (pedel) ${ }^{52}$.

\section{FURTHER LIVES OF THE APPLICANTS FOR THE POST OF SECRETARY OF THE UNIVERSITY OF LWÓW}

After being awarded the title of professor extraordinarius, Marceli Chlamtacz continued his scholarly career at the University of Lwów but from 1908 he also embarked on a career in the local government. He was a councillor on the Lwów City Council for many years and in the years 1918-1927 he was deputy mayor for the City of Lwów ${ }^{53}$.

The other (rejected) candidates pursued their careers in various walks of life and professions. Jan Józef Wierzbowski, who withdrew his application before the announcement of the result, worked as a judge and barrister in Stanisławów where

${ }^{50}$ ДАЛО, ф. 26, оп. 5, спр. 1989, арк. 3, 3v.

${ }^{51}$ R. Wiaderna-Kuśnierz, Prawo rzymskie na Uniwersytecie Jana Kazimierza ..., pp. 184-185; Kronika Uniwersytetu Lwowskiego (1898/9-1909/10), vol. 2, collated by W. Hahn, Lwów 1912, pp. 683-684.

${ }^{52}$ Kronika Uniwersytetu Lwowskiego 1894/95-1897/98..., pp. 254-255.

${ }_{53}$ More information on the professor's life and work in the publications is listed in footnotes $2-6$ of this paper. 
he was a well-known and respected figure ${ }^{54}$. He never started his own family. He died on 4 March 1939 in Stanisławów as a retired judge ${ }^{55}$. Not much is known about Kazimierz Tychowski. He probably died in the defence of Lwów in 1918. It was difficult to find information about Jan Błeszyński's life. However, it was possible to establish a few facts and find a few of his publications which prove that he pursued his passion for the theatre, literature and art and wrote about them. He signed them Jan H. Błeszyński (as mentioned his second name was Honoriusz) ${ }^{56}$.

Adam Redzik described broadly the life and professional activity of Aleksander Doliński (another rejected candidate) in the article entitled Aleksander Doliński (1866-1930). Professor of commercial law at the Jan Kazimierz University in Lwów (Aleksander Doliński (1866-1930). Profesor prawa handlowego Uniwersytetu Jana Kazimierza we Lwowie) ${ }^{57}$. In 1895 Doliński was habilitated in Austrian private law $^{58}$. In 1899 he was included in the list of barristers of the Bar in Lwów ${ }^{59}$ while in 1904 he was awarded the title of professor extraordinarius of commercial law and bill of exchange law at Lwów University. Due to his nomination, he was forced to resign from advocacy which he did. He was awarded the title of professor ordinarius of commercial law and bill of exchange law 5 years later, in August

${ }^{54}$ He particularly supported Polish science and youth, worked for numerous organizations and associations, i.a., Scientific Association in Lwów which he frequently supported financially (first time in 1918 when he donated 9,700 crowns in cash and bonds). Later, he donated cash and shares repeatedly which in time gave rise to Jan Wierzbowski Fund. He also funded a holiday house for craftsmen's youth in Mikuliczyn in the Carpathian Mountains. The obituary that appeared after his death in Sprawozdania Towarzystwa Naukowego we Lwowie said: "Stingy and frugal for himself to a fault, he was a quiet benefactor for a multitude of poor people whom he supported generously. Therefore, the funeral of late Jan Wierzbowski was a deserved manifestation of the whole society" (Sprawozdania Towarzystwa Naukowego we Lwowie, ed. P. Dąbkowski, vol. 19, issue 1, Lwów 1939, p. 98).

${ }^{55}$ Ibidem.

${ }^{56}$ He published the following articles (in chronological order): „Powrót taty” - najnowsza opera polska, „Kurier Niedzielny” 1897, no. 26; Teatr i muzyka. „Dziady”, „Kurier Niedzielny” 1897, no. 37. In addition, he published books: Komedya miłości, Warszawa 1902; Marokko w historii, w życiu i w pieśni wedtug opowiadań francuskiego podróżnika, Warszawa 1908. He wrote an abridged version of the book by Edward Bernstein: Strajk, jego istota i oddziatywanie (Warszawa 1907), and translated, i.a. from German to Polish, books by Arthur Shopenhauer: O religii, Dyalog (Lwów 1893) and Gniazdo rodzinne (Ognisko rodzinne). Sztuka w 4. aktach Hermana Sudermanna (Lwów1893 [translation in manuscript]).

57 A. Redzik, Aleksander Doliński..., pp. 289-325. In this article Adam Redzik invoked earlier publications connected with the death of Aleksander Doliński, i.a.: M.A.[1lerhand], Śp. Dr Aleksander Doliński, „Przegląd Prawa i Administracji” 1931, vol. 55, pp. 132-134; R. Longchamps de Bérier, Ś.P. Prof. Dr Aleksander Doliński, „Ruch Prawniczy, Ekonomiczny i Socjologiczny” 1931, p. 265; A.J.[ackowski], Śp. Dr Aleksander Doliński, „Gazeta Sądowo-Warszawska” 1931, p. 253.

${ }_{58}$ Based on: O zastęstwie przy zawieraniu aktów prawnych wedlug prawa prywatnego austriackiego (Lwów 1895).

59 A. Redzik, Aleksander Doliński..., p. 296. 
$1909^{60}$. The professor left numerous publications mainly on commercial law, bill of exchange law, cooperative and insurance law. Together with Antoni Górski, he wrote the first part of a handbook of commercial law titled Outline of Commercial Law, vol. 1: General Sciences and Personal Law (Zarys prawa handlowego, vol. 1: Nauki ogólne i prawo osobowe, Lwów 1912). He died on 23 December 1930 and was buried at Łyczaków Cemetery in the tomb of Mr. and Mrs. Sławik - his parents-in-law - which is located near the tomb of Maria Konopnicka ${ }^{61}$.

Jan Waygart, the last of the barristers, became I-R adviser for the Ministry of Public Works ${ }^{62}$. After 1919, he was undersecretary at the Ministry of Military Affairs. He died in $1924^{63}$.

Translated by Bożena Sypiańska

\section{REFERENCES}

\section{Sources}

\section{Archival sources}

Державний архів львівської області, ф. 26, оп. 5, спр. 1989.

\section{Magazines}

Błeszyński J.H., ,, Powrót taty” - najnowsza opera polska, „,Kurier Niedzielny” 1897, no. 26. Błeszyński J.H., Teatr i muzyka. „Dziady”, „Kurier Niedzielny” 1897, no. 37.

${ }^{60}$ For the exact date of being awarded the title of professor, cf. ibidem, p. 292; Kronika Uniwersytetu Lwowskiego (1898/9-1909/10), p. 307.

${ }^{61}$ Adam Redzik writes that apart from his work at Lwów University, he was also a professor at a private university set up in 1922, i.e. the Higher School of Foreign Trade in Lwów. He was the Rector of the school since he was elected for this position in the autumn 1930 until his death. He was also engaged in cooperative activities and in the years 1920-1930 he was Chairman of the Chamber of Commerce and Industry and since 1923/24 he was a Member of the National Cooperative Council at the Ministry of Treasury. As Chairman of the Department of Commercial Law set up by the Act of 3 June 1919 of the Codification Commission of the Polish Republic, he took part in the work on numerous projects in the area of commercial law. He created some of them himself, e.g. the bill of exchange law and on its basis President issued an Regulation on the Bill of Exchange Law on 14 November 1924. On the basis of his report, the Department of Commercial Law adopted a project on joint-stock companies which gave rise to the Act on Law on Joint-stock Companies issued by the President in 1928. His second project on limited liability companies with further amendments (Doliński died in December 1930) constituted a basis for the Commercial Code issued in 1933. He also participated in the works on the project of the Act of Copyright Law which was passed in 1926. See A. Redzik, Aleksander Doliński..., passim.

62 Sprawozdanie c.k. Państwowej Szkoty Przemysłowej w Krakowie ogłoszone z końcem roku szkolnego 1913-14, Kraków 1914, p. 20.

${ }^{63}$ S. Zaborniak, op. cit., p. 21, footnote 24. 
Proces wytyczony Polakom w Berlinie, „Gazeta Warszawska” 1864, no. 285.

Promocye doktorskie, „Gazeta Lwowska” 11.08.1894, no. 183.

Przegląd dzienny, „Gazeta Toruńska” 13.05.1893, no. 108.

T.Z., Z dziejów rozwoju szermierki w Polsce, „Stadjon” 1927, no. 6.

\section{Literature}

A.[1lerhand] M., Śp. Dr Aleksander Doliński, „Przegląd Prawa i Administracji” 1931, vol. 55.

Bernstein E., Strajk, jego istota i oddziaływanie, ed. J. Błeszyński, Warszawa 1907.

Beskid L., Zagórski K., Robotnicy na tle przemian struktury społecznej w Polsce, Warszawa 1971.

Błeszyński J., Komedya miłości, Warszawa 1902.

Błeszyński J., Marokko w historii, w życiu i w pieśni według opowiadań francuskiego podróżnika, Warszawa 1908.

Czech-Jezierska B., Nauczanie prawa rzymskiego w Polsce w okresie międzywojennym, Lublin 2011.

Czech-Jezierska B., Okres dwudziestolecia międzywojennego a rozwój nauki prawa rzymskiego, „Zeszyty Prawnicze” 2011, no. 11.4, DOI: https://doi.org/10.21697/zp.2011.11.4.07.

Czech-Jezierska B., Prawo rzymskie i jego nauczanie w Polsce, [in:] Synteza prawa polskiego 1918 1939, eds. T. Guz, J. Głuchowski, M.R. Pałubska, Warszawa 2013.

Doliński A., O zastępstwie przy zawieraniu aktów prawnych wedlug prawa prywatnego austriackiego, Lwów 1895.

Doliński A., Górski A., Zarys prawa handlowego, vol. 1: Nauki ogólne i prawo osobowe, Lwów 1912.

J.[ackowski] A., Śp. Dr Aleksander Doliński, „Gazeta Sądowo-Warszawska” 1931.

Jaremko J., Czy wiele krajów ma tak sławna historię?, www.kuriergalicyjski.com/historia/8132-czy -wiele-krajow-ma-tak-slawna-historie [access: 14.01.2020].

Kamińska R., Marcelego Chlamtacza walka o realny charakter umowy, [in:] Ad laudem magistri nostri. Mistrzowie. Dzieła polskiej romanistyki, Torun 2018.

Kronika Uniwersytetu Lwowskiego 1894/95-1897/98, eds. L. Finkel, M. Chlamtacz, vol. 1, Lwów 1899.

Kronika Uniwersytetu Lwowskiego (1898/9-1909/10), vol. 2, collated by W. Hahn, Lwów 1912.

Longchamps de Bérier R., Ś.P. Prof. Dr Aleksander Doliński, „Ruch Prawniczy, Ekonomiczny i Socjologiczny" 1931.

Michalik J., Dzieje teatru w Krakowie w latach 1865-1893. Przedsiębiorstwa teatralne, Kraków 1996.

Najdus W., Polska Partia Socjalno-Demokratyczna Galicji i Śląska: 1890-1919, Warszawa 1983.

Nancka G., Kilka uwag o poglądach Marcelego Chlamtacza na regułę bonae fidei possessor fructus/ consumptos/ suos facit, „Z Dziejów Prawa” 2018, vol. 11(19), part 2.

Nancka G., Prawo rzymskie w pracach Marcelego Chlamtacza, Katowice 2019.

Nancka G., Trzej romaniści w poglądach Marcelego Chlamtacza, „Studia Prawno-Ekonomiczne” 2017, vol. 105.

Osuchowski W., Marcel Chlamtacz (1865-1947) [nekrolog], „Czasopismo Prawno-Historyczne” 1949, vol. 2.

Osuchowski W., Chlamtacz Marceli, [in:] Biogramy uczonych polskich: materiaty o życiu i dziatalności członków AU w Krakowie, TNW, PAU, PAN, part 1: Nauki społeczne, issue 1: $A-J$, Wrocław 1983.

Redzik A., Aleksander Doliński (1866-1930). Profesor prawa handlowego Uniwersytetu Jana Kazimierza we Lwowie, „Czasopismo Prawno-Historyczne” 2007, vol. 59(2).

Redzik A., Nauki prawne na Uniwersytecie Lwowskim, [in:] Universitati Leopoliensi trecentessimum quinquagesimum anniversarium suae fundationis celebranti In memoriam, Kraków 2011.

Redzik A., O naukach historyczno-prawnych w Uniwersytecie Jana Kazimierza we Lwowie, [in:] Nauki historycznoprawne w polskich uniwersytetach w II Rzeczypospolitej, ed. M. Pyter, Lublin 2008. 
Redzik A., Prawo prywatne na Uniwersytecie Jana Kazimierza we Lwowie, Warszawa 2009.

Redzik A., Wydziat Prawa Uniwersytetu Lwowskiego w latach 1939-1946, Lublin 2006.

Redzik A., Wiaderna-Kuśnierz R., Szachowski Stanisław Krzysztof (1838-1906), [in:] Polski Stownik Biograficzny, Warszawa 2010.

Reger W., Gilewicz A., Listy Witolda Regera wystane w latach 1896-1902 z Przemyśla do Londynu do Związku Socjalistów Polskich, Przemyśl 1961.

Shopenhauer A., Gniazdo rodzinne (Ognisko rodzinne). Sztuka w 4. aktach Hermana Sudermanna, Lwów 1893 (translation in manuscript).

Shopenhauer A., O religii, Dyalog, transl. J. Błeszyński, Lwów 1893.

Sprawozdania Towarzystwa Naukowego we Lwowie, ed. P. Dąbkowski, vol. 19, issue 1, Lwów 1939. Sprawozdanie c.k. Państwowej Szkoły Przemysłowej w Krakowie ogłoszone z końcem roku szkolnego 1913-14, Kraków 1914.

Śródka A., Uczeni polscy XIX-XX stulecia, vol. 1: A-G, Warszawa 1994.

Wiaderna-Kuśnierz R., Nauka i nauczanie prawa rzymskiego na Uniwersytecie Lwowskim w pierwszej połowie XX wieku, „Studia Prawnoustrojowe” 2007, vol. 7.

Wiaderna-Kuśnierz R., Prawo rzymskie i romaniści na lamach lwowskiego „, Przeglądu Prawa i Administracji” (1876-1939), [in:] Quid leges sine moribus? Studia nad prawem rzymskim dedykowane Profesorowi Markowi Kuryłowiczowi w 65. rocznicę urodzin i 40-lecie pracy naukowej, ed. K. Amielańczyk, Lublin 2009.

Wiaderna-Kuśnierz R., Prawo rzymskie na Uniwersytecie Jana Kazimierza we Lwowie w okresie międzywojennym (1918-1939), Torun 2015.

Wiaderna-Kuśnierz R., Wybory rektora na Uniwersytecie Jana Kazimierza we Lwowie w 1933 roku w świetle nowej ustawy o szkołach akademickich, [in:] Społeczeństwo a władza. Ustrój, prawo, idee, eds. J. Przygocki, M. Ptak, Wrocław 2010.

Wiaderna-Kuśnierz R., Zagraniczne studia i stypendia naukowe romanistów Uniwersytetu Jana Kazimierza we Lwowie, „Zeszyty Prawnicze” 2015, no. 4,

DOI: https://doi.org/10.21697/zp.2015.15.4.10.

Wolsza T., Tadeusz Bujak (1862-1926), [in:] Arcymistrzowie, mistrzowie, amatorzy... Stownik biograficzny szachistów polskich, vol. 4, Warszawa 2003.

Zaborniak S., Sportowe organizacje studenckie Lwowa i Krakowa działajace przed rejestracja Akademickiego Zwiazku Sportowego w 1909 r., [in:] Akademicka kultura fizyczna na przełomie stuleci, vol. 2: Uwarunkowania historyczno-socjologiczne, Krosno 2009.

\section{Websites}

http://teki.bkpan.poznan.pl/search.php?section=3\&single=1\&fileno=4\&page $=45$ [access: 28.12 .2019 ] . www.genealogia.okiem.pl/powstanies/index.php?nazwisko=B $\% \mathrm{C} 5 \% 82$ eszy\%C5\%84ski [access: 28.12.2019].

www.sejm-wielki.pl/b/dw.38418 [access: 28.12.2019]. 


\section{STRESZCZENIE}

Pod koniec 1894 r. Uniwersytet Lwowski ogłosił konkurs publiczny na stanowisko sekretarza uniwersytetu. Kilka miesięcy później na uniwersytet wpłynęło siedem wniosków od młodych prawników. Po przeprowadzonej rekrutacji zwycięzcą został dr Marceli Chlamtacz, młody naukowiec zajmujący się tematyką prawa rzymskiego, dla którego był to jeden z etapów jego kariery naukowej. W pierwszej części niniejszego artykułu omówiono m.in. okoliczności wyborów i osiągnięcia zawodowe kandydatów do czasu wyborów. W drugiej zaś przedstawiono wyniki wyborów i wspomniano o późniejszych karierach prawników, po 1895 r. Oprócz M. Chlamtacza ubiegali się o powyższe stanowisko tak znane w późniejszym okresie osobistości, jak: Aleksander Doliński - profesor prawa handlowego na Uniwersytecie Jana Kazimierza we Lwowie, współautor Kodeksu handlowego; Tadeusz Bujak - sędzia sądów w Krakowie, Wiedniu i Warszawie; Jan Wierzbowski - adwokat i sędzia w Stanisławowie, filantrop i darczyńca Lwowskiego Towarzystwa Naukowego; Jan Waygart - posiadał stopień doktora nauk prawnych, specjalista w sprawach wojskowych w dziedzinie wymiaru sprawiedliwości, podsekretarz stanu w Ministerstwie Spraw Wojskowych; Jan Błeszyński - doktor prawa Uniwersytetu Jagiellońskiego w Krakowie, ekspert w dziedzinie teatru, literatury i thumaczeń. Ostatnim, który złożył wniosek o wspomniane stanowisko, był nieznany szerzej Kazimierz Tychowski - narodowości ukraińskiej absolwent prawa.

Słowa kluczowe: Uniwersytet Lwowski; Uniwersytet Jana Kazimierza; prawo rzymskie; prawo cywilne; prawo handlowe; Lwów; Kresy; Marceli Chlamtacz; Aleksander Doliński; Tadeusz Bujak; Jan Wierzbowski; Jan Waygart; Kazimierz Tychowski; Jan Błeszyński; sędzia; adwokat 